\title{
The Effect of Salt and Acid on Physicochemical, Microbiological and Organoleptic Properties of Salted Fermented Mackerel (Rastrelliger Brachysoma)
}

\author{
Subiyanto $^{1, *}$, Evi Liviawaty ${ }^{2}$, Emma Rochima $^{2}$, Asti Sawitri $^{3}$, Siti Ainun Nisah ${ }^{2}$, Eddy Afrianto $^{2}$ \\ ${ }^{1}$ Department of Marine Science, Faculty of Fishery and Marine Science, \\ Universitas Padjadjaran, Sumedang, Indonesia \\ ${ }^{2}$ Department of Fishery, Faculty of Fishery and Marine Science, \\ Universitas Padjadjaran, Sumedang, Indonesia \\ ${ }^{3}$ Department of Physics, Universitas Halim Sanusi, Bandung, Indonesia \\ *corresponding author: subiyanto@unpad.ac.id
}

Received: June 6, 2021. Revised: December 21, 2021. Accepted: January 16, 2022. Published: January 24, 2022

\begin{abstract}
This paper aims to find the best composition for adding salt to the manufacture of fermented mackerel (Restrelliger Branchysoma). The addition of salt in sufficient quantities can kill microbes or pathogenic bacteria but produce a taste that is too salty. This is one of the causes of the lack of public interest in consuming salted fish. The addition of acid solution and the addition of starter bacteria is an effort to reduce the salt content used, besides that it can grow a lot of fermented microbes. In this paper, the addition of salt and acid solution is carried out. The results obtained in this paper, making fermented mackerel using vinegar with a fermentation time of $\mathbf{1 4}$ days is the most effective treatment in producing fermented mackerel products. This fermented mackerel has an aroma that is liked and accepted by panelists and produces a distinctive, savory and not so salty taste.
\end{abstract}

Keywords- Environmental control; Fermentation; MRS Broth; Lactic acid bacteria; Vinegar.

\section{INTRODUCTION}

$\mathrm{F}$ ERMENTATION is a traditional processing technique to decompose complex compounds into simple compounds [1]. Decomposition is carried out by utilizing microbial activity in suitable (controlled) organic substrates, the composition of compounds in the material becomes more diverse due to fermentation so that fermented products have various uniqueness and advantages [2]. In the fermentation process, certain microbes are used to produce acid or other components that can inhibit other microorganisms that destroy the fermentation process, besides inhibiting the growth of unwanted microorganisms, it can also improve the nutritional value of the product [3]. The uniqueness of fermented products, among others, has a distinctive appearance, odor, taste, and texture [4].

Fermented mackerel is one of the most popular fermented products. Fermented mackerel is one of the products of spontaneous fermentation, namely fermentation without the addition of a starter, so that the quality of the product is not fixed from time to time. The fermentation process in making fermented mackerel is a process of breaking down complex fat and protein compounds contained in fish meat into simpler compounds with the help of enzymes derived from the fish's own body or microorganisms [5]. Spontaneous fermentation is usually the number and type of microbes that participate actively vary which causes the quality of the final product to be different and not uniform, the final quality obtained is uncertain. The raw material commonly used to make fermented mackerel is mackerel (Restrelliger sp.). However, the fermented mackerel that is in great demand by the public is the fermented mackerel made from female mackerel (Restrelliger Branchysoma) because female mackerel has a savorier taste male mackerel [6]. The use of mackerel as a raw material for fermented mackerel is because mackerel has a low degree of dryness when dried for salted fish products, so it is more suitable to be fermented or fermented with a salt such as fermented mackerel [7].

Fermented mackerel manufacture generally uses high salt content. The addition of salt in sufficient quantities can aim to kill pathogenic microbes or bacteria but produce a taste that is too salty. This is one of the causes of the lack of public interest in consuming salted fish. It is known that salt acts as a selector 
for pathogenic and spoilage microbes, because salt binds water in food so that it cannot be used by microbes [7]. The use of high salt levels is not good for human health, where high salt levels can cause hypertension for all genders and ages [8][11]. Hypertension is known as the silent killer. It is one of the causative factors for chronic kidney disease, heart failure, stroke etc. [12]. Therefore, salt for the fermentation process must be reduced. However, the reduction of salt causes the fermentation process to be disrupted and fail. Environmental characteristics that can stimulate microbial growth during fermentation greatly assist the success of the fermentation process and reduce the use of high salt content. Acidic solutions such as vinegar can lower the $\mathrm{pH}$ of the fish which will create a suitable environment for the growth of fermenting microbes. Therefore, the addition of an acid solution is an attempt to reduce the salt content used and can grow a lot of fermenting microbes. In this study, we compared the fermentation treatment using salt and acid. The use of acid is expected to be able to control microbial growth in the environment such as the use of salt. In addition, the use of acid in the fermentation process is good for health because of the reduced salt content in fermented mackerel. Salt intake reduction can prevent hypertension and contribute to the reduction of blood pressure in the hypertensive patient receive medical therapy [13].

\section{MATERIALS AND METHODS}

\section{A. Materials}

Mackerel (Restrainer Branchysoma) were obtained from the local market in Ciroyom, Bandung, Indonesia. Salt and vinegar were obtained from a local market in Tanjungsari, Sumedang, Indonesia. MRS Broth and Buffer $\mathrm{pH} 4$ and 7 were obtained from MERCK.

\section{B. Fermented Rastrelliger Brachysoma}

The control environmental (CE) for mackerel fermentation was carried out using salt with a concentration of $25 \%$ wt. This is done for 3 days. The mackerel fermentation was carried out with two treatments, namely the addition of $3 \%$ salt and $3 \%$ vinegar immersion for 14 days (H-14) and 21 days (H-21). The addition of $3 \%$ salt and $3 \%$ vinegar was carried out after done control environmental. Fermented mackerel were analyzed, $\mathrm{pH}$ [14], moisture [15], salt content [15], and microbiological total plate count (TPC) test [16].

\section{Organoleptic Properties}

The organoleptic was the observation parameters namely the appearance, odour and taste of the Fermented mackerel. This test was supported by 15 panelists. The panelists will provide their responses regarding the level of preference for the product. This organoleptic test uses a tool in the form of a score sheet, panelist was provided with a questionnaire sheet containing a score sheet containing the level of preference for characteristics in the form of numbers from a scale of 1 to 9 , the product acceptance limit was 5, meaning that if the panelist gave a score of 5 , the panelist was still declared to like that product.

\section{Statistical analysis}

In this paper, the statistical test used are the Kruskal-Wallis Test and Mann-Whitney U Test. The Kruskal-Wallis test is a ranking-based nonparametric test whose purpose is to determine whether there are statistically significant differences between two or more groups of independent variables on the dependent variable on a numerical data scale (interval/ratio) and an ordinal scale. Because the Kruskal-Wallis test is an omnibus test, which is a test that can only find out whether there is a statistically significant difference without being able to know which treatments are different, a Post Hoc test is needed. The Post Hoc test used in this paper is the MannWhitney U Test. The Mann-Whitney U Test is also known as the Wilcoxon Rank Sum Test. It is a non-parametric test option if the Independent $\mathrm{T}$ Test cannot be carried out because the normality assumption is not met.

\section{RESULTS AND DISCUSSION}

Research on the formation of odour and taste in mackerel through additional treatment of salt and acid media for the growth of fermented microbes has been carried out. This research was conducted by testing the moisture, $\mathrm{pH}$ level, salt content, the total value of bacteria and the level of preference. This test is based on organoleptic characteristics, namely the appearance, odour, texture and taste of the mackerel produced for 21 days. The effect of salt and vinegar on moisture, $\mathrm{pH}$, and salt content is presented in Table 1.

Table 1. Effect of addition salt and vinegar of moisture, $\mathrm{pH}$, and salt content.

\begin{tabular}{cccc}
\hline $\begin{array}{c}\text { Fermented } \\
\text { Treatment }\end{array}$ & Moisture (\%) & pH & $\begin{array}{c}\text { Salt content } \\
(\boldsymbol{\%})\end{array}$ \\
\hline CE & 72.5 & 6.10 & 0.81 \\
Salt H-14 & 59.5 & 7.30 & 13.2 \\
Salt H-21 & 59.5 & 7.50 & 17.1 \\
Vinegar H-14 & 0.57 & 6.40 & 8.50 \\
Vinegar H-21 & 0.63 & 6.40 & 7.60 \\
\hline
\end{tabular}

\section{A. Moisture}

Moisture is a fairly accurate indicator of the susceptibility of a product to quality deterioration because it will have an impact on the potential rate of chemical reactions such as oxidation [17]. In Table 1, it can be seen that the largest moisture is the $\mathrm{CE}$ at $72.5 \%$, while the lowest moisture is the vinegar $\mathrm{H}-14$ at $0.57 \%$. The reduction in moisture is due to the addition of salt in the CE process. The moisture decreases with increasing salt content [18]. The lowest moisture was obtained by immersion in vinegar. This happens because of the large number of broken hydrogen bonds in collagen so that the bonds between the constituent amino acids are getting weaker. This affects the amount of water that is entangled in the bond, where the binding strength of water molecules decreases and causes the moisture to decrease [19]. 


\section{B. $p H$}

Based on Table 1, the lowest $\mathrm{pH}$ value was obtained from the vinegar immersion treatment on days 14 and 21 where the $\mathrm{pH}$ value of the two treatments was 6.4. The highest $\mathrm{pH}$ value was obtained from the salt $\mathrm{H}-21$ of 7.5 . The $\mathrm{pH}$ of the sample in the immersion treatment with salt solution decreased from the $\mathrm{CE} \mathrm{pH}$. The decrease in $\mathrm{pH}$ is thought to be due to the large amount of lactic acid produced by lactic acid bacteria in their metabolism so that the $\mathrm{pH}$ of the media becomes acidic and unsuitable for other microorganisms [20]. Lactic acid bacteria can generally grow at a $\mathrm{pH}$ of 4-4.5; however, certain strains are tolerant and can grow at a $\mathrm{pH}$ of 9 or as low as 3.2 [21]. In additional treatment with $3 \%$ vinegar solution, the $\mathrm{pH}$ decreased due to vinegar immersion causing the fish's body to become acidic and the fish's $\mathrm{pH}$ to decrease.

\section{Salt Content}

Based on Table 1, the highest salt content value in the salt $\mathrm{H}-21$ at $17.10 \%$, while the smallest value was obtained from the vinegar $\mathrm{H}-21$ at $7.59 \%$, while the salt content in $\mathrm{CE}$ at $0.81 \%$. The increase in salt levels in the fish's body in the salt solution immersion treatment is due to the use of the amount of salt used and the process of salt diffusion between fish and the environment caused by differences in salt concentrations between the environment and fish. The diffusion process ends when the environmental and salt concentrations are balanced and equal. The salt content of salted fish tends to increase along with the increase in the concentration of the salt solution and the duration of immersion [22]. The decrease in salt content in the vinegar solution was thought to be due to the breakdown of the $\mathrm{NaCl}$ complex into its constituent molecules, namely $\mathrm{Na}+$ and $\mathrm{Cl}$ - ions. $\mathrm{Na}+$ ions are utilized by lactic acid bacteria for their growth process. where at that time is the initial growth period of bacteria so that the required amount of $\mathrm{Na}+$ ions is greater because, in addition to the growth process, it is also needed for the adaptation process to new environmental conditions.

\section{Microbiological Analysis}

Changes in total plate count (TPC) for fermented mackerel during fermentation with salt and vinegar soaking treatment are shown in Figure 1. The highest TPC value was found in the vinegar $\mathrm{H}-21$ at $101.4 \times 10^{6}$ colonies $/ \mathrm{ml}$, while the treatment salt H-14 was the smallest value at $0.41 \times 10^{6}$ colonies $/ \mathrm{ml}$.

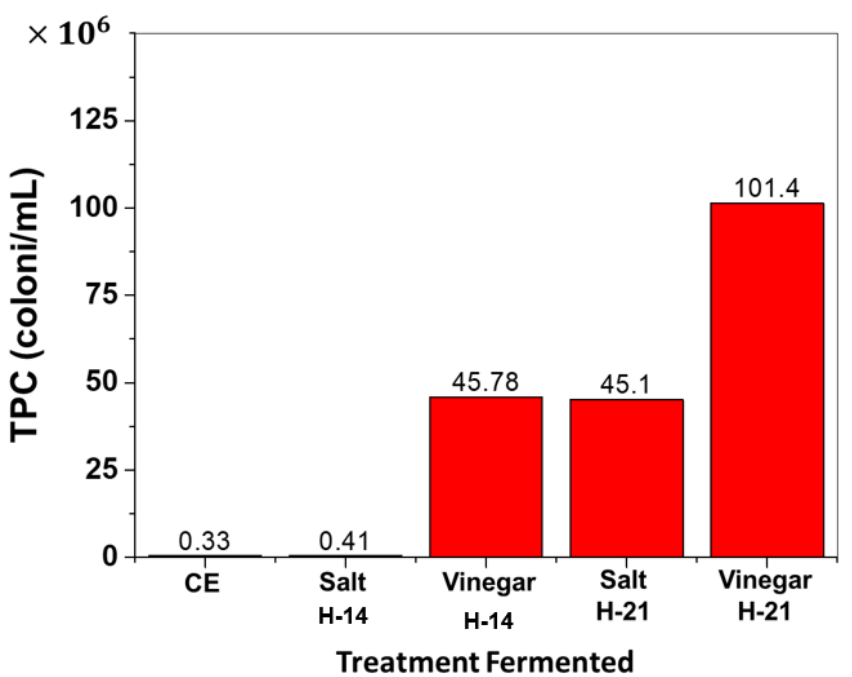

Figure 1. The total plate count (TPC) of fermented mackerel (Rastrelliger Brachysoma).

In each treatment there was an increase in the number of fermented microbial colonies each week, the increase in the number of microbial colonies was due to the addition of salt in $\mathrm{CE}$ which could stimulate the growth of lactic acid bacteria. The use of salt at the beginning of the fermentation process is very important to create a suitable environment for the growth of fermenting bacteria, where salt is a selector for growing bacteria. Salt concentration affects the total number of halophilic bacteria, but the length of fermentation time will also affect the number [23]. The increase in TPC increased in the vinegar immersion treatment because of the low $\mathrm{pH}$ value and very low moisture, thus increasing the number of lactic acid bacteria in fish.

\section{E. The Analysis of Organoleptic Quality}

The organoleptic test was carried out with observation parameters, namely the appearance, texture, odour and taste of the fermented mackerel. The results of organoleptic tests on mackerel fish with various fermentation treatments are shown in Table 2.

Table 2. Kruskal-Wallis Test Results

\begin{tabular}{|ll|r|r|}
\hline \multicolumn{2}{|c|}{ Ranks } \\
\hline & Fermented & & \\
& Treatment & N & Mean Rank \\
\hline Appearance & 'CE' & 20 & 83.80 \\
& 'Salt H-14' & 20 & 54.38 \\
& 'Vinegar H-14' & 20 & 38.10 \\
& 'Salt H-21' & 20 & 56.43 \\
& 'Vinegar H-21' & 20 & 19.80 \\
& Total & 100 & \\
\hline Texture & 'CE' & 20 & 78.58 \\
& 'Salt H-14' & 20 & 48.28 \\
'Vinegar H-14' & 20 & 56.18 \\
'Salt H-21' & 20 & 39.03 \\
\hline
\end{tabular}




\begin{tabular}{|ll|r|r|} 
& 'Vinegar H-21' & 20 & 30.45 \\
& Total & 100 & \\
\hline Odour & 'CE' & 20 & 73.18 \\
& 'Salt H-14' & 20 & 44.38 \\
& 'Vinegar H-14' & 20 & 56.30 \\
& 'Salt H-21' & 20 & 39.20 \\
& 'Vinegar H-21' & 20 & 39.45 \\
& Total & 20 & \\
\hline Taste & 'CE' & 20 & 31.30 \\
& 'Salt H-14' & 20 & 61.50 \\
& 'Vinegar H-14' & 20 & 63.83 \\
& 'Salt H-21' & 20 & 64.00 \\
'Vinegar H-21' & 100 & 31.88 \\
& Total & \\
\hline
\end{tabular}

Test Statistics ${ }^{a, b}$

\begin{tabular}{|l|r|r|r|r|}
\hline & Appearance & Texture & Odour & \multicolumn{1}{c|}{ Taste } \\
\hline Chi-Square & 58.303 & 36.505 & 22.211 & 34.384 \\
df & 4 & 4 & 4 & 4 \\
Asymp. Sig. & .000 & .000 & .000 & .000 \\
\hline
\end{tabular}

a. Kruskal Wallis Test

b. Grouping Variable: Fermented Treatment

Based on the results of the Kruskal Wallis test in Table 2, it is shown that there are differences for each fermented treatment in appearance, texture, odor and taste. Therefore, it is continued with a further test or also called a post hoc test. The post hoc test used in this paper is the Mann Whitney U test. With this test, it is possible to assess whether there are significant differences between categories. The results of the Mann Whitney U test are shown in Table 3 - Table 12.

Table 3. Mann-Whitney Test between CE and Salt H-14

Test Statistics ${ }^{\mathrm{a}}$

\begin{tabular}{|l|r|r|r|r|}
\hline & Appearance & Texture & Odour & \multicolumn{1}{c|}{ Taste } \\
\hline Mann-Whitney U & 51.500 & 64.500 & 78.500 & 88.000 \\
Wilcoxon W & 261.500 & 274.500 & 288.500 & 298.000 \\
Z & -4.272 & -3.917 & -3.525 & -3.258 \\
Asymp. Sig. (2- & .000 & .000 & .000 & .001 \\
tailed) & $.000^{\mathrm{b}}$ & $.000^{\mathrm{b}}$ & $.001^{\mathrm{b}}$ & $.002^{\mathrm{b}}$ \\
$\begin{array}{l}\text { Exact Sig. [2*(1- } \\
\text { tailed Sig.)] }\end{array}$ & & & & \\
\hline
\end{tabular}

a. Grouping Variable: Fermented Treatment

b. Not corrected for ties.

Table 4. Mann-Whitney Test between CE and Vinegar H-14

Test Statistics ${ }^{\mathrm{a}}$

\begin{tabular}{|l|r|r|r|r|}
\hline & Appearance & Texture & Odour & \multicolumn{1}{c|}{ Taste } \\
\hline Mann-Whitney U & 34.000 & 93.000 & 138.500 & 66.000 \\
Wilcoxon W & 244.000 & 303.000 & 348.500 & 276.000 \\
Z & -4.688 & -3.136 & -1.776 & -4.007 \\
Asymp. Sig. (2- & .000 & .002 & .076 & .000 \\
tailed) & & & &
\end{tabular}

\begin{tabular}{|c|c|c|c|c|}
\hline $\begin{array}{l}\text { Exact Sig. [2*(1- } \\
\text { tailed Sig.)] }\end{array}$ & $.000^{\mathrm{b}}$ & $.003^{b}$ & $.096^{\mathrm{b}}$ & $.000^{\mathrm{b}}$ \\
\hline
\end{tabular}

a. Grouping Variable: Fermented Treatment

b. Not corrected for ties.

Table 5. Mann-Whitney Test between CE and Salt H-21

Test Statistics ${ }^{\mathrm{a}}$

\begin{tabular}{|l|r|r|r|r|}
\hline & Appearance & Texture & Odour & \multicolumn{1}{c|}{ Taste } \\
\hline Mann-Whitney U & 48.500 & 51.000 & 68.000 & 60.000 \\
Wilcoxon W & 258.500 & 261.000 & 278.000 & 270.000 \\
Z & -4.395 & -4.204 & -3.815 & -4.284 \\
Asymp. Sig. (2- & .000 & .000 & .000 & .000 \\
tailed) & & & & \\
Exact Sig. [2*(1- & $.000^{\mathrm{b}}$ & $.000^{\mathrm{b}}$ & $.000^{\mathrm{b}}$ & $.000^{\mathrm{b}}$ \\
tailed Sig.)] & & & & \\
\hline
\end{tabular}

a. Grouping Variable: Fermented Treatment

b. Not corrected for ties.

Table 6. Mann-Whitney Test between CE and Vinegar H-21

Test Statistics ${ }^{\mathrm{a}}$

\begin{tabular}{|l|r|r|r|r|}
\hline & Appearance & Texture & Odour & Taste \\
\hline Mann-Whitney U & .000 & 30.000 & 61.500 & 198.000 \\
Wilcoxon W & 210.000 & 240.000 & 271.500 & 408.000 \\
Z & -5.637 & -4.770 & -3.990 & -.061 \\
Asymp. Sig. (2- & .000 & .000 & .000 & .951 \\
tailed) & & & & \\
$\begin{array}{l}\text { Exact Sig. [2*(1- } \\
\text { tailed Sig.)] }\end{array}$ & $.000^{\mathrm{b}}$ & $.000^{\mathrm{b}}$ & $.000^{\mathrm{b}}$ & $.968^{\mathrm{b}}$ \\
\hline
\end{tabular}

a. Grouping Variable: Fermented Treatment

b. Not corrected for ties.

Table 7. Mann-Whitney Test between Salt H-14 and Vinegar H-14

Test Statistics ${ }^{\mathrm{a}}$

\begin{tabular}{|l|r|r|r|r|}
\hline & Appearance & Texture & Odour & \multicolumn{1}{c|}{ Taste } \\
\hline Mann-Whitney U & 122.000 & 159.500 & 153.500 & 198.000 \\
Wilcoxon W & 332.000 & 369.500 & 363.500 & 408.000 \\
Z & -2.302 & -1.226 & -1.328 & -.060 \\
Asymp. Sig. (2- & .021 & .220 & .184 & .952 \\
tailed) & & & & \\
$\begin{array}{l}\text { Exact Sig. [2*(1- } \\
\text { tailed Sig.)] }\end{array}$ & $.035^{\mathrm{b}}$ & $.277^{\mathrm{b}}$ & $.211^{\mathrm{b}}$ & $.968^{\mathrm{b}}$ \\
\hline
\end{tabular}

a. Grouping Variable: Fermented Treatment

b. Not corrected for ties.

Table 8. Mann-Whitney Test between Salt H-14 and Salt H-21

Test Statistics ${ }^{\mathrm{a}}$

\begin{tabular}{|l|r|r|r|r|}
\hline & Appearance & Texture & Odour & Taste \\
\hline Mann-Whitney U & 186.500 & 155.500 & 176.000 & 200.000 \\
Wilcoxon W & 396.500 & 365.500 & 386.000 & 410.000 \\
Z & -.409 & -1.339 & -.714 & .000 \\
Asymp. Sig. (2- & .683 & .181 & .475 & 1.000 \\
tailed) & & & & \\
$\begin{array}{l}\text { Exact Sig. [2*(1- } \\
\text { tailed Sig.)] }\end{array}$ & $.718^{\mathrm{b}}$ & $.231^{\mathrm{b}}$ & $.529^{\mathrm{b}}$ & $1.000^{\mathrm{b}}$ \\
\hline \multicolumn{2}{|l|}{ a. Grouping Variable: Fermented Treatment } \\
\hline
\end{tabular}


b. Not corrected for ties.

Table 9. Mann-Whitney Test between Salt H-14 and Vinegar $\mathrm{H}-21$

Test Statistics ${ }^{\mathrm{a}}$

\begin{tabular}{|l|r|r|r|r|}
\hline & Appearance & Texture & Odour & \multicolumn{1}{c|}{ Taste } \\
\hline Mann-Whitney U & 38.500 & 113.000 & 178.500 & 90.000 \\
Wilcoxon W & 248.500 & 323.000 & 388.500 & 300.000 \\
Z & -4.685 & -2.646 & -.636 & -3.170 \\
$\begin{array}{l}\text { Asymp. Sig. (2- } \\
\text { tailed) }\end{array}$ & .000 & .008 & .525 & .002 \\
$\begin{array}{l}\text { Exact Sig. [2*(1- } \\
\text { tailed Sig.)] }\end{array}$ & $.000^{\mathrm{b}}$ & $.018^{\mathrm{b}}$ & $.565^{\mathrm{b}}$ & $.002^{\mathrm{b}}$ \\
\hline
\end{tabular}

a. Grouping Variable: Fermented Treatment

b. Not corrected for ties.

Table 10. Mann-Whitney Test between Vinegar H-14 and Salt H-21

Test Statistics ${ }^{\mathrm{a}}$

\begin{tabular}{|l|r|r|r|r|}
\hline & Appearance & Texture & Odour & Taste \\
\hline Mann-Whitney U & 112.000 & 128.000 & 134.000 & 197.500 \\
Wilcoxon W & 322.000 & 338.000 & 344.000 & 407.500 \\
Z & -2.563 & -2.095 & -1.903 & -.085 \\
Asymp. Sig. (2- & .010 & .036 & .057 & .932 \\
tailed) & & & & \\
Exact Sig. [2*(1- & $.017^{\mathrm{b}}$ & $.052^{\mathrm{b}}$ & $.076^{\mathrm{b}}$ & $.947^{\mathrm{b}}$ \\
tailed Sig.)] & & & & \\
\hline
\end{tabular}

a. Grouping Variable: Fermented Treatment

b. Not corrected for ties.

Table 11. Mann-Whitney Test between Vinegar H-14 and Vinegar H-21

Test Statistics ${ }^{\text {a }}$

\begin{tabular}{|l|r|r|r|r|}
\hline & Appearance & Texture & Odour & \multicolumn{1}{c|}{ Taste } \\
\hline Mann-Whitney U & 116.000 & 92.000 & 135.000 & 72.000 \\
Wilcoxon W & 326.000 & 302.000 & 345.000 & 282.000 \\
Z & -2.515 & -3.125 & -1.870 & -3.835 \\
Asymp. Sig. (2- & .012 & .002 & .061 & .000 \\
tailed) & & & & \\
Exact Sig. [2*(1- & $.023^{\mathrm{b}}$ & $.003^{\mathrm{b}}$ & $.081^{\mathrm{b}}$ & $.000^{\mathrm{b}}$ \\
tailed Sig.)] & & & & \\
\hline
\end{tabular}

a. Grouping Variable: Fermented Treatment

b. Not corrected for ties.

Table 12. Mann-Whitney Test between Salt H-21 and Vinegar H-21

Test Statistics ${ }^{\mathrm{a}}$

\begin{tabular}{|l|r|r|r|r|}
\hline & Appearance & Texture & Odour & \multicolumn{1}{c|}{ Taste } \\
\hline Mann-Whitney U & 31.500 & 164.000 & 196.000 & 67.500 \\
Wilcoxon W & 241.500 & 374.000 & 406.000 & 277.500 \\
Z & -4.841 & -1.059 & -.122 & -4.082 \\
Asymp. Sig. (2- & .000 & .289 & .903 & .000 \\
tailed) & & & & \\
Exact Sig. [2*(1- \\
tailed Sig.)]
\end{tabular}

a. Grouping Variable: Fermented Treatment

b. Not corrected for ties.

Table 13. The analysis of organoleptic quality of fermented mackerel (Rastrelliger Brachysoma)

\begin{tabular}{|l|r|r|r|r|}
\hline \multicolumn{1}{|c}{ Average } \\
\hline 'CE' & Appearance & Texture & Odour & \multicolumn{1}{c|}{ Taste } \\
'Salt H-14' & 8.3 & 7.5 & 6.3 & 5.8 \\
'Vinegar H-14' & 6.1 & 5.5 & 4.5 & 7.4 \\
'Salt H-21' & 5.0 & 5.9 & 5.4 & 7.5 \\
'Vinegar H-21' & 6.2 & 4.9 & 4.2 & 7.5 \\
\hline
\end{tabular}

Based on Table 13, the results of panelists' observations of fermented mackerel with various treatments showed an average value ranging from 3.7 to 8.3 . Appearance is one of the parameters in determining the acceptance of a product by consumers. The appearance will give rise to a good impression or not according to the level of preference of the panelists for the product, if the impression of appearance is good and liked, the panelists will observe other organoleptic parameters such as odor, texture, and taste in the product [23]. The appearance characteristics of fermented mackerel are largely determined by the raw materials and enzyme activity of the bacteria [24]. In the addition of salt and vinegar immersion treatment, there was an average increase in the appearance criteria because the appearance of the fish was dry, had a brownish white color on the body of the fermented mackerel and the meat of the fermented mackerel was already reddened. In general, a good fermented mackerel that is liked by consumers has bright red meat [25]. Kruskal-Wallis test and Mann-Whitney test results showed that the addition of vinegar solution and the addition of salt gave different effects on the appearance characteristics of fermented mackerel with a mean rank value ranging from 19.80-83.80. In this case, it is stated that the product of each treatment is unacceptable or unfavorable until it is highly favored by the panelists. From the average value shown in Table 13, fermented mackerel with $\mathrm{H}-21$ vinegar immersion was not acceptable to the panelists while other treatments were still acceptable to the panelists until they were very favored by the panelists.

The texture of a food material is closely related to the moisture in the food. In Table 13, it can be seen that the results of observations by panelists on the texture parameters of fermented mackerel obtained an average value ranging from 4.4 to 7.5. The texture of the fermented mackerel in the addition of salt and vinegar on days 14 and 21 has a hard texture that is slightly soft, the meat is slightly moist. This is because the moisture in the fish body is low. The use of salt at the beginning of CE resulted in low fish moisture and dry meat texture [18]. Kruskal-Wallis test and Mann-Whitney test results showed that the addition of vinegar solution and the addition of salt gave no different effect on the texture characteristics of fermented mackerel with a mean rank value ranging from 30.45-78.58, which means that the texture 
characteristics of fermented mackerel were still acceptable to the panelists until they were liked by the panelists. The largest mean rank value was found in the control treatment and the addition of $\mathrm{H}-13$ vinegar with a mean rank value of 56.18 , it means that the panelists liked the texture of the treatment, while for other treatments the mean rank value was below 50, i.e. the researcher still received the texture of the treatment.

Based on the results of observations by panelists on the odour of fermented mackerel from each treatment, the average value of the odour characteristics ranged from 4.2 to 6.3 (Table 13). Based on the data obtained, the average value of the addition of salt treatment experienced a not so large increase. This is presumably due to the addition of the number of microbes present in the product, the protein and fat reshuffling activity carried out by fermented microbes will produce a distinctive odour in the product so that the panelists prefer to add $\mathrm{H}-21$ salt to the addition of $\mathrm{H}-14$ salt. The average value of the vinegar immersion treatment decreased. This is presumably because the vinegar solution is a solution that has a very pungent odor, the sour odour is absorbed into the fish's body which makes the fish have a strong sour odour. The longer the fermentation, the stronger the odour will be. The results of the Kruskal-Wallis test and Mann-Whitney test showed that the addition of a solution of vinegar and the addition of salt had a different effect on the characteristics of the odour of fermented mackerel with a mean rank value ranging from 39.20-73.18. In this case, it is stated that the product of each treatment is unacceptable or unfavorable until it is liked by the panelists. The mean rank value of the characteristic odour of fermented mackerel was the largest in the control treatment while for the treatment and vinegar immersion on $\mathrm{H}-14$, the addition of salt on $\mathrm{H}-14$ and $\mathrm{H}-21$ was still normal or accepted by the panelists.

Taste is a very important factor in determining the consumer's final decision to accept or reject food. Although, the other assessment parameters are good, but the taste can determine to like or dislike in the acceptance of the product. Based on the results of observations by panelists on the taste characteristics of fermented mackerel, the average value ranged from 5.7 to 7.5 (Table 13). In the addition of salt treatment, there was an increase in the average value. This is thought to be caused by the increased growth of fermenting bacteria in the fish body so that the distinctive taste of the product is getting stronger and favored by the panelists. Meanwhile, in the vinegar immersion treatment, the average value decreased. This is because the longer the fermentation period, the sourer the fermented mackerel will be due to the acid absorption process. Kruskal-Wallis test and MannWhitney test results showed that the addition of vinegar solution and the addition of salt gave no different effect on the taste characteristics of fermented mackerel with mean rank values ranging from 31.30-64.00. this means that the taste characteristics of fermented mackerel can still be accepted by the panelists until they are liked by the panelists. The largest median value was found in the addition of salt on $\mathrm{H}-21$ and vinegar immersion on $\mathrm{H}-14$ with a mean rank value of 64.00 and 63.83 respectively. this means that the taste in the treatment was favored by the panelists while the control treatment and vinegar immersion on $\mathrm{H}-21$ were less preferred but still acceptable by the panelists.

\section{CONCLUSIONS}

The best treatment for making fermented mackerel is treatment with vinegar soaking with a fermentation time of 14 days. From the tests that have been carried out by using vinegar soaking in $\mathrm{H}-14$, the moisture is $0.57 \%$, $\mathrm{pH} 6.40$, the total bacteria value (TPC) is $45.78 \times 10^{6}$ colonies $/ \mathrm{ml}$ and the salt content is 8.50 . \% . Based on an organoleptic assessment by panelists, vinegar soaking treatment with fermentation for 14 days was the best treatment with a mean rank value and an average appearance of 38.10 with an average of 5.0, the median value of odour 56.30 with an average of 5.4 , the median value of texture 56.18 with an average of 5.9 , the median value of taste 63.83 with an average of 7.5 . From this value, the vinegar immersion treatment with a fermentation time of 14 days was acceptable and favored by the panelists. The fermented mackerel using vinegar with a fermentation time of 14 days is the most effective treatment in producing fermented mackerel products. This fermented mackerel has an aroma that is liked and accepted by panelists and produces a distinctive, savory and not so salty taste.

\section{ACKNOWLEDGMENT}

The research was supported by the Ministry of Research and Technology/National Research and Innovation Agency 2021, through the Basic Research grant with contract number 1207/UN6.3.1/PT.00/2021. The author would also like to thank the Dean of the Faculty of Fishery and Marine Science, Universitas Padjadjaran and the Directorate of Research and Community Service (DRPM).

\section{REFERENCES}

[1] F. J. Marti-Quijal, F. Remize, G. Meca, E. Ferrer, M. J. Ruiz, and F. J. Barba, "Fermentation in fish and byproducts processing: an overview of current research and future prospects," Current Opinion in Food Science, vol. 31, pp. 9-16, 2020.

[2] S. Yang et al., "Fermentation temperature affects yogurt quality: A metabolomics study," Food Bioscience, vol. 42, no. May, p. 101104, 2021.

[3] M. Oryza.S et al., "Physico-Chemical Characteristics and Amino Acid Content Evaluation of Citric Acid by-Product Produced by Microbial Fermentation as a Potential Use in Animal Feed," Fermentation, vol. 7, no. 3, p. 149, 2021.

[4] E. Afrianto, E. Liviawaty, Junianto, I. Rostini, and Subiyanto, "Physicochemical characteristics fish protein concentrate from cyprinus carpio," International Journal of Advanced Science and Technology, vol. 29, no. 5, pp. 169-173, 2020.

[5] J. E. Park et al., "Mackerel-derived fermented fish oil protects skin against UVB-induced cellular damage by 
inhibiting oxidative stress," Journal of Functional Foods, vol. 46, no. October 2017, pp. 147-158, 2018.

[6] F. R. Indaryanto, H. Imai, and Y. Wardiatno, "Genetic variation of short body mackerel, Rastrelliger brachysoma of Jawa Island, Indonesia based on mtDNA control region sequences," AACL Bioflux, vol. 8, no. 5, pp. 648-655, 2015.

[7] O. Das, S. H. Kumar, and B. B. Nayak, "Relative abundance of halophilic archaea and bacteria in diverse salt-fermented fish products," Lwt, vol. 117, no. September 2019, p. 108688, 2020.

[8] P. Yang et al., "Protective effect of oral histidine on hypertension in Dahl salt-sensitive rats induced by highsalt diet," Life Sciences, vol. 270, no. December 2020, p. 119134, 2021.

[9] S. Naqvi et al., "A cross-talk between gut microbiome, salt and hypertension," Biomedicine and Pharmacotherapy, vol. 134, p. 111156, 2021.

[10] M. F. Teodoro and C. S. I. M. Ao, "Notes about Pediatrics Hypertension Literacy," WSEAS TRANSACTIONS on BIOLOGY and BIOMEDICINE, vol. 14, pp. 89-97, 2017.

[11]H. W. Park, E. Batbaatar, D. Li, and K. H. Ryu, "Risk factors rule mining in hypertension: Korean National Health and Nutrient Examinations Survey 2007-2014," CIBCB 2016 - Annual IEEE International Conference on Computational Intelligence in Bioinformatics and Computational Biology, pp. 4-7, 2016.

[12] S. Vijh, D. Gaur, and S. Kumar, "Diet recommendation for hypertension patient on basis of nutrient using AHP and entropy," Proceedings of the Confluence 2020 - 10th International Conference on Cloud Computing, Data Science and Engineering, pp. 364-368, 2020.

[13] T. M. Frisoli, R. E. Schmieder, T. Grodzicki, and F. H. Messerli, "Salt and hypertension: Is salt dietary reduction worth the effort?," American Journal of Medicine, vol. 125, no. 5, pp. 433-439, 2012.

[14]E. Afrianto and E. Livyawati, Fish Processing and Preservation (Pengawetan dan Pengolahan Ikan). Yogyakarta: Kanisius, 1989.

[15]AOAC, Official Methodas of Analysis, 18th ed. Washington DC: Association of Officiating Analytical Chemists, 2005.

[16] S. Fardiaz, Practical Guidance for Food Microbiological quality analysis (Mikrobiologi Pangan Penuntun Praktikum). Bogor: Department Food Technology and Nutrition, Bogor Institute of Agriculture, 1989.

[17] I. Jeyasanta, S. Prakash, and J. Patterson, "Wet and dry salting processing of double spotted queen fish Scomberoides lysan (Forsskål, 1775) Immaculate," International Journal of Fisheries and Aquatic Studies, vol. 3, no. 4, pp. 330-338, 2016.

[18]H. M. A. Sulieman and O. A. M. Khamis, "Effect of Salt Concentration Level and Season on Chemical Composition of Wet-Salted Fermented Fish Species," vol. 2, no. 1, pp. 10-16, 2012.

[19] C. Litaay and J. Santoso, "Pengaruh Perbedaan Metode Perendaman dan Lama Perendaman terhadap
Karakteristik Fisiko-Kimia Tepung Ikan Cakalang (Katsuwonus pelamis)," Ilmu dan Teknologi Kelautan Tropis, vol. 5, no. 1, pp. 85-92, 2013.

[20] W. C. Frazier and D. C. Westhoff, Food Microbiology, 4th ed. New York: McGraw-Hill, 1988.

[21]C. W. Bamforth, Food, Fermentation and Microorganisms. UK: Blackwell Science, 2005.

[22] R. Rahmani, Y. Yuianta, and E. Martati, "Effect of Wet Salting Method on the Characteristic of Salted Snakedhead Fish ( Ophiocepalus striatus )," Jurnal Teknologi Pertanian, vol. 8, no. 3, pp. 142-152, 2003.

[23]B. Kilinc, S. Cakli, S. Tolasa, and T. Dincer, "Chemical, microbiological and sensory changes associated with fish sauce processing," European Food Research and Technology, vol. 222, no. 5-6, pp. 604-613, 2006.

[24] J. P. Tamang, "Ethnic fermented foods and alcoholic beverages of Asia," in Springer, no. October, 2016, pp. 341-382.

[25]H. E. Irianto, Produk Fermentasi Ikan, 1st ed. Jakarta: Penebar Swadaya, 2013.

Creative Commons Attribution License 4.0 (Attribution 4.0 International, CC BY 4.0)

This article is published under the terms of the Creative Commons Attribution License 4.0

https://creativecommons.org/licenses/by/4.0/deed.en US 